\title{
AGRICULTURAL BIOTECHNOLOGY AND POVERTY REDUCTION IN SOUTH ASIA
}

\author{
M. Hasan, M. I. Khan ${ }^{1}$ and N. A. Ivy \\ Department of Genetics and Plant Breeding, Bangabandhu Sheikh Mujibur Rahman \\ Agricultural University, Salna, Gazipur-1706, Bangladesh
}

\begin{abstract}
South Asian countries have made remarkable advances in food production accompanied by a dramatic reduction of poverty during the past two decades. This has been due to the result of trade and investment reforms, which have generated economic growth in this region. Despite these changes South Asia generates only $2 \%$ of the global income, yet supports $22 \%$ of the world's population and $44 \%$ of the world's poor. Over $75 \%$ of the population depends directly or indirectly on agriculture for their livelihoods. Therefore, agriculture will play a major role in the future and massive productivity increases and product diversification will be required. Due to escalating population and urbanization, natural resources are gradually depleting posing major challenges to reduce poverty in this region. The problems confronting these countries are complex and enormous of which the major issues are; declining agricultural land and agricultural population, marginal producers with small land holdings, decreasing per capita land availability, conflicting demands for scarce water resource, urbanization and youth evading traditional farming. This region will be required to produce food for larger and larger populations from less and lees land. The biggest challenge is how to increase output from the shrinking agricultural sector, while sustaining the productivity potential of the available natural resources. The agricultural production systems are changing rapidly in these countries, trend being intensive agriculture using high- tech that provides maximum potential benefit of improved crop germplasm. Agriculture is the largest contributor to the economies of many countries of the developing world. Agricultural biotechnology, which comprises a wide range of biological disciplines, offers enormous potential to speed up the development of plant varieties with pro-poor traits such as drought tolerance, pest resistance or tolerance, higher yields, increased nutritional value, among others. While biotechnology does not provide the 'silver bullet' for poverty alleviation, it does enhance the effectiveness of other disciplines such as plant breeding, integrated pest and nutrient management, and livestock breeding, feeding and disease management.
\end{abstract}

Key Words : Biotechnology, Poverty, South Asia

1 Department of Agricultural Economics, Bangabandhu Sheikh Mujibur Rahman Agricultural University, Salna, Gazipur-1706, Bangladesh 


\section{Background}

In the past 20 years, South Asian countries have generated economic growth and strengthened their macro-economies by implementing production, trade and investment reforms. Despite of these changes, the total contribution of global trade has remained at $1 \%$. South Asia also generates less than $2 \%$ of the world's income, yet supports $22 \%$ of the world's population and $44 \%$ of the world's poor. Most of these people are dependant on agriculture for their livelihoods and survival. Approximately $60 \%$ of the Asian labor are involved in agriculture which accounts for about $25 \%$ of South Asia's GDP. More than $2 / 3$ of the rural population derives their livelihoods from land. To feed the increasing population adequately, it is estimated that food production has to be doubled within the next 30 years. Meeting this demand will require massive productivity increases and product diversification to ensure broad based economic growth capable of improving the livelihoods of the poor. Therefore, agriculture and rural development should receive priority and policies and appropriate technologies will have to play a dominant role for the upliftment of living standards of the poor in this region.

\section{Potential role of biotechnology}

Agriculture is the most important economic activity in Asia and offers the means to reverse these trends and to stimulate wider economic growth. Due to rapid increase in human population, there is need to produce more food on less land, with less water, while conserving the environment.

Although the continent's GDP has improved over the years, the proportion of people living in absolute poverty is higher than it was in the 1980s and 1990s (UNDP 2005). There is very limited opportunity for poor people to participate meaningfully in the economy as either producers of goods and services or as suppliers of labor.

Science and technology are recognized globally as drivers of increased wealth and continuously improving standards of living. The role of science and technological innovation in economic change and sustainable development is receiving attention at national, regional and international levels. There is ample evidence that economic advances in the developed and newly industrializing countries are results of technological and organizational innovations (Mokyr, 2002). Scientifically and technologically advanced countries have become continuously wealthier, and their rates of growth have not slowed significantly over time (Pritchett, 1995). These countries have succeeded by reinvesting a growing percentage of their gross domestic product (GDP) in further advancement of research. Translation of research into new, more efficient modes of production has brought dramatic benefits. Technological innovation is associated with turning scientific knowledge into products and processes: putting new technologies and their products on the market and incrementally modifying and adjusting them to respond to socio-economic conditions (Juma, 2005). Some of the East Asian countries that capitalized on these opportunities have transformed themselves into middle- or highincome economies (Nankani, 2005). 
Application of knowledge through new technologies will provide opportunities for improving developing country economies and the well-being of the people, and offer a means for increasing agricultural production, improving human health, and addressing environmental degradation.

In agriculture, advances in biotechnology have resulted in improved research leading to: drought resistant crop varieties; increased pest and disease resistance in crops and livestock; new, refined diagnostics and vaccines for livestock diseases (e.g. Foot-andMouth disease and East Coast fever); rapid propagation of clean planting material e.g. flowers, vegetables, bananas etc. (Sharma, 2001).

Current constraints to the research and application of biotechnology in developing countries include: lack of policies; lack of human and financial resources; lack of public and private investments at levels that can make a difference; absence of systems for the delivery of technologies to potential users; lack of awareness, leading to misconceptions about the potential of, and risks posed by, biotechnology.

There is now ample evidence to demonstrate the opportunities offered by biotechnology in developing economies. Two examples are given here, from China and India.

\section{China}

In the early 1980s Chinese leaders decided that science and technology (S\&T), especially biotechnology, would be one of the drivers to improve the agricultural sector, and committed substantial public investments in biotechnology, e.g. rice biotechnology (mapping rice genome), cotton biotechnology for insect resistance, production of valueadded horticultural crops, and complimentary innovations such as use of nematodes for biological pest control leading to increased export markets. Currently, over 5 million small farmers are growing Bt-cotton on 1 million hectares of land in China (Zhong et al., 2006). Use of biological control has reduced pesticide use on cotton by $30 \%$ nationally. Today, horticultural exports are expanding. Thus, through a deliberate effort to revolutionize agriculture, China is making quantum leaps in agricultural productivity and sustainability improvements. The country is now moving to the 'post-Green Revolution era' towards becoming an industrialized nation. As has been pointed out above, an efficient agricultural sector ensures food security and enables industrial development.

\section{India}

India's National Dairy Development Board (NDDB) oversees improved dairy production by millions of smallholder livestock producers, including many women. Success in using increased milk production to generate increased income on a daily basis is the result of investments in S\&T targeting: improved feeding and nutrition of dairy cattle; vaccines to control endemic diseases; and improved animal genotypes and their delivery to farmers. The NDDB organizes delivery of services (including biotechnologies) at the points of milk collection. Payments for technical services are affordable and deducted from milk 
payments to smallholders. In the 1960s and 1970s India regularly had famines and was a net food importing country. The Green-Revolution in crops and the White Revolution in dairy production are the result of investments in S\&T and infrastructure, especially irrigation and communications and the formulation and implementation of supportive public policies (prices, trade etc.) to encourage farmers to go into production. India is now using its productive agricultural sector to guarantee food security and is moving towards industrialization.

Although there are still millions of people living in poverty in South Asia the trends in India are heading in the right direction, with millions moving out of poverty each year (Moulick et al., 2007).

\section{Present status of biotechnology in Bangladesh}

The programme on plant biotechnology in Bangladesh was initiated in late 1970s in the Department of Botany, Dhaka University with tissue culture of jute. Thereafter within a span of 10-12 years tissue culture research laboratories have developed in different universities and $R \& D$ organizations. As a result of intensive work on plant tissue culture protocols on plant regeneration and micro-propagation have been developed on different crops, forest plants, ornamental and fruit trees as well as vegetables. These in vitro regeneration protocols are now awaiting for commercial exploitation. It is expected that with the establishment of private entrepreneurs commercial utilization and expansion of tissue culture techniques will gradually find its due place in Bangladesh.

The Technical committee on Crop Biotechnology of the Ministry of Agriculture has approved the confinement trial of golden rice at the BRRI. The most popular rice varieties of BRRI - BR 29 and BR 28 have been transformed at IRRI. The golden rice transformants of BR-29 is already under trial in glass house condition at BRRI. This would not any increase in the yield of the rice crop but would supply vitamin A to the consumers whether they need it or not.

Brinjal is a very popular vegetable available to our country throughout the year. Its cultivation requires huge amount of insecticidal spray to check the fruit and shoot borer, a serious pest of the crop. Thus the committee has also given approval of importing Bt brinjal and late blight resistant potato GM lines for further research under confined conditions at BARI.

Potato is now an important crop in Bangladesh. One of the main problems of potato cultivation is its susceptibility to late blight disease caused by Phytopthora infestants. The GM lines of potato resistant to late blight are now available. The technical committee has also approved the import of transgenic 'Katahdin' with RB gene for potato late blight resistance developed at Wisconsin State University, USA for contained green house research at Biotech Division in BARI. The improved microtubers and in vitro plantlets will be multiplied and screened against late blight and subsequently crossed and backcrossed with promising and high yielding varieties of Bangladesh. 
In the field of molecular characterization of crop varieties, it is the BAU which took the leadership in organizing morpho-molecular characterization of plant varieties for their protection. The other important project areas of BAU are development of transgenic protocols for transformation of rice and Brassica varieties with saline resistance genes.

The University of Dhaka is working on the breeding of salt tolerant rice varieties with the aid of molecular markers. Agrobacterium-mediated gene transformation on cereal and vegetable crops has also been initiated in the Department of Botany, Rajshahi University (Bhuiyan, 2007).

\section{Animal and Insect Biotechnology and Aquaculture}

In animal biotechnology Bangladesh Livestock Research Institute (BLRI) and Bangladesh Agricultural University (BAU) have already taken modern biotechnology programmes. These include embryo transfer technology, multiple ovulation embryo transfer and artificial insemination programme.

Biotechnology in fisheries induces spawing in carp, pabda, catfish, koi and others. With this technology 50,000 kg of different fish species can now be produced annually.

Sericulture Research Institute, Rajshahi has been working for a long time for the improvement of sericulture production in Bangladesh. During recent past genetic engineering techniques have also been adopted for the purpose. At the Bangladesh Atomic Energy Commission low dose of gamma radiation to the silkworm has been employed for the enhanced production of silk. Significant progress has been achievement on sterile insect technique (SIT) by utilizing gamma radiation (Nayyum et al., 2007). Besides, hormonal and pheromonal control of insects and also the integrated pest management programme are now being adopted for insect management. Isolation and characterization of Bacillus thuringiensis strains for the control of Lepidopteran insects has been initiated at the University of Dhaka.

\section{Industrial biotechnology}

In the filed of industrial biotechnology Bangladesh is yet to make real breakthroughs. Modern biotechnological programmes involving gene transfer technology have yet to be started in real earnestness. Whatever has been possible is through classical/old biotechnology methods. However, the results are quite encouraging and a good number of projects are in advanced stage which can be taken up for commercialization.

\section{Bioenergy}

A significant achievement has been made in the filed of 'BIOGAS' production from animal excreta (cowdung) and agricultural residues. The Institute of Fuel Research and Development (IFRD) has been working since long in this field. As a result of research findings and its subsequent development in collaboration with Department of Energy (DOE) at present more than 10,000 biogas plants throughout the country has also been taken up by the Government which is now under implementation. 


\section{Technology development for poverty alleviation}

There is considerable evidence that agricultural research has led to significant increases in productivity and enhanced incomes in developing countries (Lipton and Longhurst, 1989; Kerr and Kolavalli, 1999). The development of improved cultivars and management practices, mechanization, improved plant nutrition and crop protection technologies have been in the forefront of agricultural technologies contributing to increased crop yields in many developing countries. The Green Revolution, which is commonly referred to as "seed revolution" which predominated in the early 1960s contributed to unprecedented increases in food production, wheat and rice yields increased by several folds. Due to the impact of green revolution the incidence of rural poverty declined as agricultural growth and purchasing power of the people rose. Advances in agricultural science and technology has increased productivity, hence it will be an important drive to improve food and nutritional security and reducing the number of poor in the coming years. As more than $90 \%$ of the of the food consumed in poor countries are produced locally, the efficiency of production has to be improved for the well being of the poor, through the use of appropriate technologies.

However, innovations in agricultural research alone will not reduce poverty in the absence of poverty-focused policy and action. It is noted that the agricultural research policies often does not mention poverty alleviation as a specific target. In many of the Asian countries reforms and structural adjustments have had positive impact on productivity but poverty levels remained static, sometimes increasing. To have effective research on poverty alleviation, governments should incorporate criteria such as equity and poverty focus into market driven agricultural development. This means that the voice of the small farmers in agricultural research in market integrated agricultural systems should be strengthened. This is because large farmers or commercial agriculturists have a greater influence over the agricultural agendas, leaving the small farmers with technology problems that are inappropriate for the reasons of scale, cost, managerial complexity or simply because they are irrelevant to the main problems of market integration. (Rukini et al., 1998).

\section{Emerging research trends}

All the countries of South Asia are pinning great hopes on agricultural biotechnology to alleviate poverty and hunger. Biotechnology seems to offer unlimited potentials for solving old and new problems. Most of the countries in the region are in the process of developing manpower in this area. Some countries such as India have gone far ahead in this process by not only developing the skilled manpower, but also investing in the infrastructure for research. Most of the smaller nations are struggling to achieve in this field, often constrained by brain drain and inadequate infrastructure. Although the biotechnological research is costly its application will be within the reach of the farmers and other users in the Asian region, they will also require skills in their application, hence at the beginning only the progressive farmers may adopt the technologies (Sharma et al., 2001). The pro-poor features of biotechnology will include reduction in the cost of production with the use of less expensive inputs such as bio fertilizers, biological 
management of pests, detection of pathogens and their bio control and applicability of biotechnological tools in a wide range of conditions for dry and marginal lands. There are also other features of biotechnology, which could be used in conjunction with traditional farming practices.

\section{CONCLUSION}

Economic development in developing countries will, of necessity, have to be initially linked to agriculture (broadly defined to include crop, livestock, forestry and fish). Staple crops and livestock are the most likely to promote economic growth in the continent. To date, public sector investment in biotechnology in developing countries has led to few products. This has, in part, been due to lack of viable private sector partners who are able and willing to take new products to markets. There is also a critical need for innovative public/private sector partnerships which will help link public investments in R\&D with private 'know-how' and technology for product development.

The scientists of Bangladesh are trying their level best to get significant achievement in the field of biotechnology. They are working on Bt brinjal and late blight resiatant potato GM lines. In the field of molecular characterization of crop varieties, Bangladesh Agricultural University (BAU) took the leadership in organizing morpho-molecular characterization of plant varieties for their protection. The other important project areas of BAU are development of transgenic protocols for transformation of rice and Brassica varieties with saline resistance genes.

For biotechnology to create wealth, at least the following must happen: there has to be a clear definition of priorities/targets (participatory research can assist in target identification); the best of relevant science regardless of where it comes from around the world must be mobilized and adapted to address the identified targets (a mechanism for proactive identification of new, relevant science must be put in place); and a critical mass of resources (human and financial) must be available for the targets to be met. In addition, the local private sector and communities need to be involved in product development and commercialization so that new technologies can be both affordable and accessible. Further, more delivery mechanisms have to be developed so that new (bio) technologies are accessible to those who need them.

\section{REFERENCES}

Bhuiyan, S. R. 2007. Biotechnology and its Use in Plant Breeding and Crop Production. $7^{\text {th }}$ Annual Conference Plant Breeding and Genetics Society of Bangladesh.

Juma, C. 2005. Going for growth: Science, technology and innovation in Africa. The Smith Institute, London, UK.

Kerr, J. and Shashi K. 1999. Impact of agricultural research on poverty alleviation. Conceptual framework with illustrations from the literature. Draft paper prepared for IAEG and IFPRI, Washington DC.

Lipton, M. and Richard L. 1989. New seeds and poor people. Baltimore. Johns Hopkins Press. 
Mokyr, J. 2002. The gifts of Athena: Historical origins of the knowledge economy. Princeton University Press, Princeton, New Jersey, USA.

Moulick, S. K., McDowell, L. D., Van, V. and Guha, H. 2007. Potential of Deshi Cattle of India for Dairy Production. J. Dairy Sci., 55 : 1148-1155.

Nankani, G. 2005. Knowledge for productivitity-led growth. In : Juma, C. (ed), Going for growth: Science, technology and innovation in Africa. The Smith Institute, London, UK. pp. 23-32.

Nayyum, C. 2007. Promotion of Biotechnology in Bangladesh: National and International Perspectives. Conference held on April 06-08, Dhaka, Bangladesh.

Pritchett, L. 1995. Divergence, big time. World Bank Policy Research Working Paper 1522. Background paper for World Bank Development Report 1995. The World Bank, Washington, DC, USA.

Rukini, M. and Eicher, C. K. 1998. Crafting smallholder driven agricultural research systems on southern Africa. World Develop., 26(6) : 1073-1087.

Sharma, H. C., Sharma, K. K., Seetharama, N. and Ortiz, R. 2001. Genetic transformation of crop plants: Risks and opportunities for the rural poor. Current Sci., 80 : 1495-1508.

UNDP (United Nations Development Programme). 2005. International cooperation at a crossroads: Aid, trade and security in an unequal world. UNDP Human Development Report, 2005. UNDP. New York, USA.

Zhong, W. and Chen J. 2006. Environmental Biotechnology in China : Prog. Prosp.. Biotech. J., 11 : 1241-1252. 